\title{
Comparison of Degrees of Social Distance Towards the Mentally III Between Relatives of Psychiatric Patients, Health Workers and the General Public
}

\author{
Chukwujekwu Donald Chidozie ${ }^{1, *}$, Chukwujekwu Judith Chioma ${ }^{2}$, \\ Olose Emmanuel Omamurhomu ${ }^{3}$ \\ ${ }^{1}$ Department of Neuropsychiatry, University of Port Harcourt Teaching Hospital, Port Harcourt, Rivers State, Nigeria \\ ${ }^{2}$ Department of Educational Management, University of Port Harcourt, Port Harcourt, Rivers State, Nigeria \\ ${ }^{3}$ Department of Psychiatry, University of Calabar, Calabar, Cross River State, Nigeria \\ Email address: \\ chidozie.chukwujekwu@uniport.edu.ng (C. D. Chidozie) \\ ${ }^{*}$ Corresponding author
}

To cite this article:

Chukwujekwu Donald Chidozie, Chukwujekwu Judith Chioma, Olose Emmanuel Omamurhomu. Comparison of Degrees of Social Distance Towards the Mentally Ill Between Relatives of Psychiatric Patients, Health Workers and the General Public. American Journal of Psychiatry and Neuroscience. Vol. 4, No. 3, 2016, pp. 48-51. doi: 10.11648/j.ajpn.20160403.13

Received: April 30, 2016; Accepted: May 9, 2016; Published: May 26, 2016

\begin{abstract}
The study compared the degree of social distance towards the mentally ill between the public, health workers and relatives of the mentally ill at Madonna University Teaching Hospital, Elele, Rivers State of Nigeria. It took place within 10 months. Two hundred and sixty nine consenting subjects were enlisted in the study. However only 254 completed it comprising 110 relatives of the mentally ill, 47 health workers and 97 non-relatives (public). The modified Bogardus Social Distance Scale (MBSDS) and a self designed questionnaire containing socio-demographic and psychiatric illness variables were administered to each subject. The difference in mean MBSDS scores of the public and relatives of the mentally ill is statistically significant, while the difference in mean MBSDS scores of the public and health workers is not statistically significant. The greatest proportion of respondents (37\%) attributed the cause of mentally illness to demonic possession. Stigma towards the mentally ill is not only an important global health concern, but it is a burning human right issue.
\end{abstract}

Keywords: Stigma, Mentally-Ill, Social Distance, Health, Scores

\section{Introduction}

Psychopharmacology and rehabilitation strategies that address psychiatric diseases and their sequale have been developed and evaluated. Nevertheless, effective management of mental illness has continued to pose great challenges to practitioners of behavioral sciences because of a myriad of problems among which are the twin malady of stigma and discrimination. The confusing and complex concept of the mind and brain as well as African mythology and superstition has strengthened these negative attitudes towards the mentally ill in our environment.

Stigma is the negative evaluation of a person as tainted or discredited on the basis of attributes, such as mental disorder, ethnicity, drug misuse or physical disorder. [1] According to
Carrigan and Penn, stigma is another term for prejudice based on negative stereotyping [2].

A rationale is thus constructed for devaluing, rejecting and excluding such persons. [3] Stigma towards the mentally ill including the negative and rejecting attitudes by members of the community have implications for prevention, early treatment, rehabilitation and quality of life of the sufferers. [4]

Such stigma significantly impedes the opportunities of persons who had serious mental illness such as Schizophrenia and Bipolar Disorder [1]. It has been identified as a major problem in North America and Western European Communities. [5, 6, 7, 8, 9]

Social distance is a proxy measure of behavioral discrimination and reflects the individual's self report on his willingness to engage persons with mental illness in activities 
that involve varying degree of intimacy. [10, 11, 12, 13]

Stigma and social distance is a dimension of suffering that is more devastating, life limiting and long lasting than the mental illness itself. Several studies in social psychiatry have illuminated the important role that cultural beliefs play in shaping societal responses to people with mental illness [14, $15,16]$. However, there have been suggestions that stigma and social distance are less evident in African countries. [17]

In Nigeria, studies on attitudes and social distance towards mental illness and the mentally ill are few. Most of these studies were carried out in the Western geographical region of the country which is mainly populated by the Yoruba [18, $19,20,21,22]$. Nigeria is a culturally diverse country and her components parts are dissimilar in their access to mental health services [21].

Studies aimed at elucidating the underlying factors for discriminating against the mentally ill sought for answers in the demographic characteristics of the subjects. However, results of these studies are sometimes contradicting.

This study is aimed at comparing the degree of social distance towards the mentally ill between the public, health workers and relatives of the mentally ill at Madonna University Teaching Hospital Elele, Rivers State. This will help clarify whether proximity to the mentally ill or orthodox/medical education would help in our advocacy against the hydra-headed monster of stigma and discrimination towards the mentally ill.

\section{Materials and Methods}

This prospective cross-sectional study was conducted at Madonna University Teaching Hospital Elele, Rivers State, Nigeria within a period of 10 months.

\subsection{Instruments}

For this study, the instruments employed are as follows:-

1 The modified Bogardus Social Distance Scale (MBSDS)

2 A self designed, semi-structured, self administered questionnaire containing socio-demographic and psychiatric illness variables.

The Bogardus social distance scale is a psychological testing scale created by Emory S. Bogardus to empirically measure people's willingness to participate in social contacts of varying degrees of closeness with members of diverse social groups such as racial and ethnic groups. The scale asks people the extent to which they would be accepting of each group (a score of 1.00 for a group is taken to indicate no social distance) [10].

For this study, the modified version of Bogardus Social Distance Scale (MBSDS) developed by Link [11 \& 12] was used. The MBSDS was presented in a likert form. Questions asked include:- How would you feel having the mentally ill presented as

1 Your Landlord

2 Your co-worker

3 Your neighbor
4 Your friend

5 Your Business Associate

6 Your In - law

7 Your Child care provider

For each of these questions, there are 5 options (Likert Format) from which the subject is expected to choose one with its corresponding score:-

$\begin{array}{lr}\text { In any case } & \text { Score } 1 \\ \text { Maybe but I have my reservation - } & 2 \\ \text { Maybe but with definite conditions } & 3 \\ \text { Difficult to accept but maybe - } & 4 \\ \text { In no case at all - } & 5\end{array}$

A score of 1 indicates no social distance

A score of 5 indicates maximum social distance

The reliability of the scale, assessed by means of Cronbach's alpha, is 0.9 [11]

\subsection{Procedure}

Before the commencement of this study, informed consent was obtained from all the subjects. Two hundred and sixtynine (269) subjects enlisted in the study but only two hundred and fifty-four (254) completed it. The two hundred and fiftyfour (254) subjects comprise 110 relatives of the mentally ill, 47 health workers and 97 non-relatives. A relative of every other psychiatry patient who attended the psychiatric clinic within the stated period participated in the study.

The health workers and the non-relatives of the mentally ill were selected randomly. The two questionnaires specified above were administered to each subject. The total score of the modified BSDS were calculated for each subject.

\section{Results}

Table 1. Distribution of the Various Groups of Subjects in the Cohort.

\begin{tabular}{lll}
\hline Group of Subject & Frequency & Percentage \% \\
\hline Public & 97 & 38.2 \\
Health Workers & 47 & 18.5 \\
Relatives of the Mentally ill & 110 & 43.3 \\
Total & 254 & 100 \\
\hline
\end{tabular}

Table 2. Distribution of the Total Bogardus Scores for the Various Groups.

\begin{tabular}{lll}
\hline Group of Subject & $\begin{array}{l}\text { Total Bogardus } \\
\text { score }\end{array}$ & $\begin{array}{l}\text { Average Bogardus } \\
\text { score \% }\end{array}$ \\
\hline Public & 2,800 & $28.9 \pm 6.1$ \\
Health Workers & 1,157 & $24.6 \pm 6.4$ \\
Relatives of the Mentally ill & 2,463 & $22.4 \pm 7.9$ \\
\hline
\end{tabular}

The difference in mean MBSDS of public and relatives of the mentally ill is statistically significant: $\mathrm{t}=0.09, d f=252$, $\mathrm{p}<0.05$.

Table 3. Familiarity with mental illness.

\begin{tabular}{lll}
\hline Response & Frequency & $\mathbf{\%}$ \\
\hline Yes & 223 & 87.8 \\
No & 30 & 11.8 \\
Nill Answer & 1 & 0.4 \\
Total & 254 & 100 \\
\hline
\end{tabular}


However the difference in mean MBSDS scores of the public and Health workers is not statistically significant: $\mathrm{t}=$ $0.08, d f=252, \mathrm{p}>0.05$.

Table 4. Causes of mental illness.

\begin{tabular}{lll}
\hline & Frequency & \% \\
\hline Sin/Punishment From God & 26 & 10.2 \\
Demonic possession & 94 & 37.0 \\
Curse & 52 & 20.5 \\
Use of Hard Drug & 51 & 20.1 \\
I don't know & 29 & 11.4 \\
Nill Answer & 1 & 0.4 \\
Total & 254 & 100 \\
\hline
\end{tabular}

Out of the two hundred and sixty nine subjects who were enlisted in the study, 254 completed it; 87 males (34.3\%) and 167 females $(65.7 \%)$. The minimum MBSDS score of 7 and the maximum score of 35 were recorded in the study. The average MBSDS score for all subjects is $25.3 \pm 6.5$.

Table 1 shows the frequency distribution of the subjects in the three different categories being compared viz: - public $(38.2 \%)$, health workers $(18.5 \%)$ and relatives of the mentally ill (43.3\%).

Table 2 depicts the total and mean Bogardus scores for the 3 different categories. The result shows that the relatives of the mentally ill patients had the least MBSDS mean score of $22.4 \pm 7.9$, followed by health workers with mean MBSDS score of $24.6 \pm 6.9$, while the general public had the highest average MBSDS score of $28.9 \pm 6.1$. The difference between the mean MBSDS of the public subgroup and that of the relatives of the mentally ill is statistically significant; $\mathrm{t}=$ $0.09, d f=252, \mathrm{p}<0.05$. However, there is no statistically significant difference between the mean MBSDS of the public and health workers; $\mathrm{t}=0.08, d f=252, \mathrm{p}=0.05$.

Table 3 shows the distribution of the subjects' responses to the question about familiarity with mental illness and the mentally ill. $87.8 \%$ reported that they are familiar with mental illness and the mentally ill. $11.8 \%$ denied this.

Table 4 displayed the subjects' responses to the question about their perceived cause of mental illness. The greatest proportion $(37 \%)$ attributed the cause of mental illness to demonic possession. This is followed by those who believed "curses" are responsible (20.5\%). 20.1\% believed mental illness results from the use of psychoactive substances. $11.4 \%$ are not sure of the cause of mental illness while $10.2 \%$ believed it is as a result of sin or punishment from God.

\section{Discussion}

Studies show that stigma is the major reason why sufferers of mental illness fail to acknowledge their illness and is the underlying factor mitigating against the social reintegration of those recovering from mental illness; and that stigmatizing attitudes cut across culture $[14,15,16]$. Nevertheless, there is paucity of work on these subjects in the undeveloped world, especially studies aimed at identifying subcultures with the most stigmatizing attitudes.

This study demonstrates that social distance towards the mentally ill is widely endorsed by the general public. This is in consonance with studies done elsewhere [17, 18, 19, 20, $21,22,23,24,25]$. On the scale of mild, moderate and severe social distance equivalent to mean MBSDS scores 7-15, 1625 , and 26-36, the public sub-cohort demonstrated severe social distance towards the mentally ill, the health workers and the relatives of the mentally ill exhibited moderate social distance towards the mentally ill. It is also important to note that the difference in attitude between the relatives of the mentally ill and the general public is statistically significant. While the relatives appear to be more tolerant than the public towards the mentally ill because of a number of factors which include empathy, blood relationship to the mentally ill as well as more interaction with the mentally ill, there still exists moderate social distance towards the mentally ill in this group of subjects (MBSDS 22.4 \pm 7.9 ), this may be explained by the influence of cultural myths, superstition and uncertainties associated with the nature, course and outcome of these behavioral aberrations $\left[\begin{array}{lll}1 & \& & 2\end{array}\right]$. This is further supported by the perceived causes of mental illness to be a demonic possession or a curse $(20.5 \%$ and $37 \%)$ among the majority of subjects.

It is an irony that health workers who should lead the campaign against stigma and discrimination, themselves are the apostles of the reverse, demonstrating moderate social distance towards the mentally ill. It appears that cultural beliefs and misconceptions about mental illness still hold sway in the minds of health workers despite several years of exposure to western education. This underscores the need for concerted effort towards a robust sustained campaign against stigma towards the mentally ill among health workers who if properly educated should champion this crusade on a larger scale $[26,27]$.

It also underscores the importance of literacy and education from the cradle, to help dispel culturally entrenched myths, ignorance, misconceptions and primordial assumptions which fuel prejudice towards the mentally ill. An eclectic approach involving traditional institutions, religious bodies as well as entrenching this policy in our academic curricula is advocated.

Furthermore, even though the calls to rename some psychiatric disorders in order to change public beliefs and attitudes towards the mentally ill remains controversial [28, 29], the expected advantages of reduced stigma and an improved communication between clinicians, patients and families as proposed by the proponents [30, 31] should motivate a more adept consideration of this initiative.

\section{Conclusion}

A major finding of the global burden of disease project was the importance of mental disorders as a cause of disease burden accounting for a quarter of the world's disability [5]. This work adds weight to the argument that stigma towards the mentally ill is not only an important global health concern, but it is a burning human right issue. 


\section{Limitation}

Whether the social distance will vary with different psychiatric diagnosis is not elucidated in the study. This is a limitation of this study.

\section{References}

[1] Goffman E. Stigma: Notes on the Management of spoiled identity, 1963. Prentice-Hall ISBN 0-671-62244-7.

[2] Corrigan P, Penn DL. Lessons from social psychology on discrediting psychiatry stigma. Am Psychologist 1999; 54: 765-776.

[3] Bruce GL, Lawrence, HY, Jo CP, Pamela C. Measuring Mental Illness Stigma. Schiz Bulletin 2004; 30 (3): 511-541.

[4] Corrigan PW, Watson AC. Understanding the impact of stigma on people with mental illness. World psychiatry 2002; 1: 16-20.

[5] Taylor SM, Dear MJ. (1980). Scaling Community Attitudes towards the mentally ill. Schizophrenia Bulletin 1980; 7: 225240 .

[6] Brockington IF, Hall P, Levinge J, Murphy C. The Community's tolerance to the mentally ill. Br J Psychiatry 1993; 162: 93-99.

[7] Huxely P. Location and Stigma; a survey of Community attitudes towards mental illness. Journ Mental Health 1991; 2: 73-80.

[8] John AF, Korten AE, Jacomb PA, Christensen H, Henderson S. (1999). Attitudes towards people with mental illness; a survey of Australian and Newzealand J Psychiatry 1999; 33: 77-83.

[9] Crips AH, Michael GG., Susannah R, Howard IM, Olwen JR. Stigmatization of people with mental illness. Br J Psychiatry 2000; 177 (1): 4-7.

[10] Link BG, Cullen FT, Frank J, and Wozhiack F. The Social Rejection of former mental patients; Understanding why labels matter. Am J Sociology 1987; 92: 1461-1500.

[11] Penn DL, Corrigan PW, Martin J, Ihnen G, Racenstein JM, Nelson D, Cassisi J, Hope D A. Social cognition and social skills in schizophrenia. The rate of self monitoring. Jour Nerv Ment Diseases 1999; 187: 188-190.

[12] Penn D. L, Guynan K, Daily T, Spalding WD, Garbin C P, Sullivas M. (1994). Dispelling the stigma of schizophrenia: what sort of information is best? Schizophrenia Bulletin 1994; 20 (3): 567-578.

[13] Schultze B, Angermeyer M C. Subjective experiences of stigma. A focus group study of schizophrenic patient, their relatives and mental health professionals. Social Sciences and Medicine 2003; 56: 299-312.

[14] Carne B. "A Consumer Perspective". Can J Com Mental Health. Special supplement 1998; (3): 21-28.

[15] Link B G, Phelan J C, Bresnaham M. Public conceptions of mental illness; Labels, Causes, Dangerousness and Social Distance. American Journal of Public Health 1999; 89: 13281333.

[16] Angermeyer M C, Matschinger, H. Casual beliefs and attitudes to people with schizophrenia; Trend analysis based on data from two population surveys in Germany. Br J Psychiatry 2005; 186: 331-334.

[17] Fabrega H. Psychiatry stigma in non-Western Societies. Compr Psychiatry 1991; 32: 534-551.

[18] Awaritefe A, Ebie JC. Complementary attitudes to mental illness in Nigeria. African J Psychiatry 1975; 1: 37-43.

[19] Binite AO. Attitudes of educational Nigerians to psychiatric illness. Acta Psych Scandanivica 1970; 46; 391-398.

[20] Gureje O, Lasebikan V, Ephraim-Oluwanuga O, Benjamin O, Lola K. Community study of knowledge of and attitude to mental illness in Nigeria. Br J Psychiatry 2005; 186: 436-441.

[21] Abiodun OA, Makanjuola ROA. Social distance towards people with mental illness amongst Nigerian University Students. Soc Psych - Psych Epidemiol 2005; 40: 865-868.

[22] Odejide AO, Olatawura MO. A survey of community attitudes to the concept and treatment of mental illness in Ibadan. Nigerian Journal of Medicine 1979; 9: 343-347.

[23] Corrigan PW. How stigma interfers with mental health care. Am Psychol 2004; 59 (7): 614-625.

[24] Ayorinde O, Gureje OA, Lawal R. (2004). Psychiatric research in Nigeria: Bridging tradition and modernization. British Journal of Psychiatry 2004; 184: 336-538.

[25] Corrigan PW, Edwards AB, Green A, Diwan SL, Penn D L. Prejudice, social distance and familiarity with mental illness. Schizophr Bull 2001; 27 (2): 219-225.

[26] Pingani L, Catellani S, Del-Vecchio V, Samogna G, Ellefson S E, Rigatilli M, Florrilo A, Evans- Lacko S, Corrigan PW. Stigma in the context of schools: analysis of the phenomenon of stigma in a population of University students. BMC Psychiatry 2016; 16: 29.

[27] Sheikh TL, Adekeye O, Olisah VO, Mohammed A. Stigmatisation of mental illness among employees of a Northern Nigeria University. Niger Med J 2015; 56 (4): 244248.

[28] Ellison N, Mason O, Scior K. Renaming Schizophrenia to reduce stigma; comparison with the case of bipolar disorder. Br J Psychiatry 2015; 206 (4): 341-342.

[29] Ellison N, Mason O, Scior K. Public beliefs about and attitudes towards bipolar disorder; testing theory based models of stigma. J Affect Disord 2015; 175: 116-123.

[30] Lasalvia A, Penta E, Sartorius N, Henderson S. Should the label "schizophrenia" be abandoned ? Schizophr Res 2015; 162 (1-3): 276-284.

[31] Imholf R. Zeroing in on the schizophrenia label on stigmatizing attitudes; a large scale study. Schizophr Bull 2016; 42 (2): 456-463. 